\title{
Prevalence of High-Risk Human Papillomavirus (HPV) among Negative Visual Inspection of Acetic Acid (VIA)
}

\author{
Prevalensi Human Papillomavirus (HPV) Risiko Tinggi pada Hasil \\ Inspeksi Visual dengan Asam Asetat (IVA) yang Negatif
}

\author{
Tofan W Utami ${ }^{1}$, Muhammad F Aziz ${ }^{1}$, Gatot Purwoto ${ }^{1}$, Alexander AW Peters ${ }^{2}$, \\ Gert J Fleuren $^{3}$, Vivian Spaans ${ }^{3}$, Sigit Purbadi ${ }^{1}$ \\ ${ }^{1}$ Department of Obstetrics and Gynecology \\ Faculty of Medicine University of Indonesia \\ Jakarta \\ ${ }^{2}$ Department of Gynecology \\ ${ }^{3}$ Department of Pathology \\ Leiden University Medical Center \\ The Netherlands
}

\begin{abstract}
Objective: Persistence of high-risk HPV infection is known to be the major cause of cervical cancer. It is important to differentiate the genotype of HPV infection, whether it is high, intermediate or low risk. The aim of this study was to assess the prevalence of high-risk HPV types among Indonesian women with negative VIA.

Method: We analyzed cervical swabs from 1,214 patients with negative VIA. By using INNO-Lipa HPV DNA test, we detected the HPV DNA and its genotype.

Result: From the 1,214 women with negative VIA, 48 (3.95\%) samples were confirmed to have positive HPV DNA by using PCR and electrophoresis. However, hybridization test were not able to detect HPV genotypes in 9 samples. These 9 samples were tested again with PCR and electrophoresis and resulted in negative HPV DNA. Among the remaining 39 samples (3.21\%), we detected 19 types of HPV, consisting of 13 types of high-risk HPV, 5 types of low-risk HPV, and 1 type of unknown HPV (type X).
\end{abstract}

Conclusion: Among patients with negative VIA, 3.21\% was found to be positive for HPV DNA. From this percentage, the prevalence of high-risk HPV is higher than the low-risk and unknown HPV. Therefore we cannot ignore results of negative VIA, particularly in highrisk group, because there is a slight possibility that presence of HPV can be identified, especially the high risk ones which have a tendency to be persistent. We support the importance of HPV DNA test as cervical cancer screening method.

[Indones J Obstet Gynecol 2014; 3: 153-156]

Keywords: cervical cancer, high-risk HPV, negative VIA

\begin{abstract}
Abstrak
Tujuan: Infeksi persisten HPV risiko tinggi merupakan penyebab utama kanker serviks. Sangatlah penting untuk mengklasifikasikan genotip dari infeksi HPV ke dalam kelompok tipe HPV risiko tinggi, menengah atau rendah. Tujuan dari penelitian ini adalah untuk mengetahui prevalensi infeksi HPV tipe risiko tinggi pada perempuan Indonesia dengan hasil pemeriksaan IVA negatif.

Metode: Dilakukan evaluasi terhadap 1214 sampel swab serviks dari subjek dengan hasil pemeriksaan IVA negatif. Dengan menggunakan tes DNA HPV INNO-Lipa, dilakukan pemeriksaan deteksi DNA HPV dan genotipnya.

Hasil: Berdasarkan pemeriksaan PCR dan elektroforesis didapatkan 48 dari 1214 subjek $(3,95 \%)$ memiliki hasil DNA HPV positif. Setelah dilakukan pemeriksaan hibridisasi, genotip HPV tidak dapat diidentifikasi pada 9 dari 48 sampel. Dilakukan pemeriksaan PCR dan elektroforesis kembali terhadap 9 sampel tersebut dan didapatkan hasil DNA HPV negatif sehingga sampel yang memiliki hasil positif DNA HPV adalah 39 sampel $(3,21 \%)$. Dari sampel tersebut ditemukan 19 tipe HPV yaitu, 13 tipe HPV risiko tinggi, 5 tipe HPV risiko rendah dan 1 tipe HPVyang tidak diketahui klasifikasinya (tipe X).

Kesimpulan: Di antara subjek dengan IVA negatif, diidentifikasi DNA HPV positif pada 3,21\% kelompok sampel. Prevalensi tipe HPV risiko tinggi lebih tinggi dibandingkan dengan HPV risiko rendah dan HPV yang belum terklasifikasi. Berdasarkan temuan ini, hasil IVA yang negatif tidak dapat diabaikan begitu saja, terutama pada kelompok risiko tinggi, karena mungkin saja sudah terinfeksi HPV tipe risiko tinggi. Temuan ini mendukung pernyataan bahwa pemeriksaan DNA HPV merupakan pemeriksaan skrining kanker serviks yang penting.

[Maj Obstet Ginekol Indones 2014; 3: 153-156]

Kata kunci: HPV risiko tinggi, IVA negatif, kanker serviks
\end{abstract}

Correspondence: Tofan W Utami. Department of Obstetrics and Gynecology, Faculty of Medicine University of Indonesia, Jakarta. Telephone: 0818859585, Email: tofanwidya@yahoo.com

\section{INTRODUCTION}

The estimated global incidence of cervical cancer in 2008 was approximately $15 \%{ }^{1}$ Cervical cancer does not only have a major impact on women's health, it is also still ranked the second leading cause of cancer-related death in women worldwide. ${ }^{1,2}$ The overall mortality rate was $60 \%$ in the entire world. ${ }^{2}$ Approximately $86 \%$ of the global 
problem of cervical cancer occur in developing countries accounting for $13 \%$ of all cancers in women. ${ }^{2}$ In Indonesia, data from the Cancer Registration Board of Association of Indonesian Pathologists show that cervical cancer ranks first of the 10 most common cancers in women in the year 2006.

The major causative factor of cervical carcinogenesis is a persistent infection of human papillomavirus (HPV). The hypothesis of the presence of a correlation between HPV infection and cervical neoplasia was first put forward by Harold zur Hausen, a German virologist. ${ }^{3}$ The relationship between HPV and cervical cancer is more significant than the relationship between smoking and lung cancer. More than 200 types of HPV have been identified based on DNA sequence data, which are grouped into high-risk HPV (HR-HPV), intermediate-risk HPV (IR-HPV), and low-risk HPV (LRHPV). ${ }^{4,5}$ Until now, there has been no study on the prevalence of HPV in Indonesia in populations that have been screened, especially involving a large number of samples. Several studies which have been conducted were carried out in the general population, patients with pre-cancerous lesions and cervical cancer. ${ }^{6-8}$ Vet et al reported the prevalence of HPV was $11.4 \%$ in the general population, while study Boer et al reported a prevalence of $25.4 \% .^{8,9}$ The types of high-risk HPV commonly found in the general population in Indonesia are types $52,16,18$, and 51 , but the prevalence still has a wide inter-study range. ${ }^{7-9}$ Type 52 is the most common type found in the general population. ${ }^{8}$ Due to that reason, it is important to differentiate the genotype of HPV infection, whether it is high, intermediate or low risk. This study aims to assess the prevalence of high-risk HPV types among Indonesian women with negative VIA.

\section{METHODS}

This study was conducted at the Obstetrics and Gynecology Clinic of Dr. Cipto Mangunkusumo hospital, health centers, and other designated healthcare facilities of the "See and Treat" Female Cancer Programme (FCP) in Jakarta, as well as at the Department of Gynecology and Department of Pathology, Leiden Universiteir Medisch Centrum (LUMC), The Netherlands. It was carried out from January 2012 to May 2013.
Subjects in this study were recruited in accordance to inclusion and exclusion criteria. We included married subjects aged 20-50 years who agreed to participate in this study, resides permanently in Jakarta and had negative VIA result. We took samples from the subjects using vaginal swab. By using INNO Lipa HPV DNA test, we detected the HPV DNA and its genotype from the samples.

\section{RESULTS}

Subjects in this study had a low risk factor for HPV infection as shown in Table 1. From 1,214 women with negative VIA, 48 (3.95\%) samples were confirmed to be positive for HPV DNA by using PCR and electrophoresis. However, HPV genotypes were not detected in 9 out of 48 samples by using hybridization test. These nine samples were tested again with PCR and electrophoresis resulting in negative HPV DNA. Among the remaining 39 samples (3.21\%), we detected 19 types of HPV consisting of 13 types of high-risk HPV, 5 types of low-risk HPV, and 1 type of unknown HPV (type X). HPV DNA test results are shown in Table 2.

Table 1. Characteristic of Subject.

\begin{tabular}{|c|c|}
\hline Variable & Description \\
\hline Age (years) & $40.9 \quad 9.28$ \\
\hline Age at first marriage (years) & $22.0 \quad 4.31$ \\
\hline \multicolumn{2}{|l|}{ Marital status subjects } \\
\hline Married one time & $1054(88.2 \%)$ \\
\hline Married more than once & $75(6.3 \%)$ \\
\hline Widow & $65(5.5 \%)$ \\
\hline \multicolumn{2}{|l|}{ Marital status couples } \\
\hline Married one time & $1060(92.6 \%)$ \\
\hline Married more than once & $84(7.4 \%)$ \\
\hline Parity & $2.3 \quad 1.57$ \\
\hline \multicolumn{2}{|l|}{ Smoking status } \\
\hline Smoke & $69(5.7 \%)$ \\
\hline Do not smoke & 1145 (94.3\%) \\
\hline
\end{tabular}


Table 2. HPV DNA Test Results.

\begin{tabular}{lcc}
\hline \hline \multicolumn{1}{c}{ Variable } & n & \% \\
\hline HPV DNA (+) & 39 & 3.21 \\
HPV DNA (-) & 1175 & 96.79 \\
High-risk HPV & 13 & 68.42 \\
Non high-risk HPV & 5 & 26.32 \\
HPV-X & 1 & 5.26 \\
\hline \hline
\end{tabular}

Nineteen types of HPV were detected, namely HPV types 6, 16, 18, 31, 39, 44, 51, 52, 53, 54, 56, $58,66,68,69,71,73,74$, and one unknown type (HPV X). HPV type 52 was identified as the most common type, with a proportion of $13 / 71$ (18.31\%). The next most common types of HPV are types 39 and $\mathrm{X}(9.86 \%)$; types 16,18, and 74 (8.45\%); and types 44, 54, and 66 (4.22\%). The proportions of HPV types detected in negative VIA patients are presented in Table 3.

Table 3. HPV Types Detected in VIA Negative Patients.

\begin{tabular}{cccc}
\hline \hline No. & HPV Type & n (71) & \%(100) \\
\hline 1. & HPV 6 & 1 & 1.41 \\
2. & HPV 16 & 6 & 8.45 \\
3. & HPV 18 & 6 & 8.45 \\
4. & HPV 31 & 1 & 1.41 \\
5. & HPV 39 & 7 & 9.86 \\
6. & HPV 44 & 3 & 4.22 \\
7. & HPV 51 & 2 & 1.41 \\
8. & HPV 52 & 13 & 18.31 \\
9. & HPV 53 & 1 & 1.41 \\
10. & HPV 54 & 3 & 4.22 \\
11. & HPV 56 & 2 & 1.41 \\
12. & HPV 58 & 2 & 1.41 \\
13. & HPV 66 & 3 & 4.22 \\
14. & HPV 68 & 2 & 1.41 \\
15. & HPV 69 & 2 & 1.41 \\
16. & HPV 71 & 2 & 1.41 \\
17. & HPV 73 & 2 & 1.41 \\
18. & HPV 74 & 6 & 8.45 \\
19. & HPV X & 7 & 9.86 \\
\hline \hline
\end{tabular}

\section{DISCUSSION}

This study showed a higher prevalence of HR-HPV compared to non HR-HPV infection in the positive HPV DNA group. Nineteen types of HPV were detected, consisting of 13 types of HR-HPV (type 16, $18,31,39,51,52,56,58,66,68,69,71$, and 73), 5 types of non-HR-HPV (type 6, 44, 53, 54, and 74), and 1 type of unknown HPV classification (HPV X).

The prevalence of HR-HPV infection in this study is higher than that reported by Carcopino, et $\mathrm{al}^{10}$ which is $21.9 \%$. Our study found that among subjects with negative VIA, HR-HPV infection was more commonly detected than non HR-HPV infection in the positive HPV DNA group. This fact implies that although the prevalence of HPV infection in subjects with negative VIA is relatively very low (3.21\%), the majority of subjects (68.42\%) had HR-HPV infection.

The more commonly identified HR-HPV plays a significant role in the natural history of cervical cancer. Persistence of HR-HPV is known to be the major cause of cervical cancer. Hopman et al conducted a study in a population with normal cytology. ${ }^{11}$ It appears that the persistence of HR-HPV infection was significantly related to the development of abnormal cytology.

More than $13 \mathrm{HPV}$ genotypes were grouped into high-risk types, which can infect epithelial cells of the basal layer of the skin or mucosal tissue. ${ }^{12,13}$ These HPV types may infect the epidermal tissue of hand and foot, and the epithelium of mouth, throat, respiratory tract, or anogenital mucosal lining. 4 Mucosal HPVs are further classified based on their ability to cause precursor lesions and cervical cancer. HR-HPV, especially type $16,18,45$, and 56 , are particularly associated with the development of cervical cancer. ${ }^{13}$ Type 16 and 18 mucosal HR-HPV are the most frequently detected HPV types in female anogenital system, and are present in $>90 \%$ cervical cancer cases, and $>50 \%$ of other anogenital invasive carcinoma. ${ }^{13,14}$

Intermediate-risk HPV (IR-HPV) are another group of HPV types which are more rarely found in cancers, but are often found in squamous intra-epithelial lesions (SIL). Low Risk-HPV (LR-HPV) type includes type $6,11,42,43$, and $44{ }^{4}$

\section{CONCLUSION}

Among the negative VIA, there was $3.21 \%$ positive HPV DNA. From this percentage, the prevalence of 
high-risk HPV is higher than the low-risk and unknown HPV. Therefore we cannot ignore results of negative VIA, particularly in high-risk group, because there is a slight possibility that presence of HPV can be identified, especially the high risk ones which have a tendency to be persistent. We support the importance of HPV DNA test as cervical cancer screening method.

\section{ACKNOWLEDGEMENT}

This research is supported by Department of Obstetrics and Gynecology, Faculty of Medicine, University of Indonesia, Jakarta, Indonesia; Department of Gynecology, Leiden University Medical Center, The Netherlands; Department of Pathology, Leiden University Medical Center, The Netherlands

\section{REFERENCES}

1. Ferlay J, Shin HR, Bray F, Forman D, Mathers C, Parkins DM. Estimates of worldwide burden of cancer in 2008: GLOBOCAN 2008. Int J Cancer 2008; 127: 2893-917.

2. WHO / ICO Information Centre on HPV and Cervical Cancer (HPV Information Centre). Human Papillomavirus and Related Cancers in World. Summary Report 2010. WHO, 2010.

3. Narisawa-Saito M, Kiyono T. Basic mechanisms of high-risk human papillomavirus-induced carcinogenesis: roles of E6 and E7 proteins. Cancer science 2007; 98(10): 1505-11.

4. Burd EM. Human papillomavirus and cervical cancer. Clinical Microbiology Reviews 2003; 16(1): 1-17.

5. Onon TS. History of human papillomavirus, warts and cancer: what do we know today? Best practice and research. Clin Obstet Gynecol 2011; 25(5): 565-74.
6. Schellekens MC, Dijkman A, Aziz MF, Siregar B, Cornain S, Kolkman-Uljee S, et al. Prevalence of single and multiple HPV types in cervical carcinomas in Jakarta, Indonesia. Gynecol Oncol. 2004; 93(1): 49-53.

7. Domingo EJ, Noviani R, Noor MR, Ngelangel CA, Limpaphayom KK, Thuan TV, et al. Epidemiology and prevention of cervical cancer in Indonesia, Malaysia, the Philippines, Thailand and Vietnam. Vaccine 2008; 26(Suppl 12): 71-9.

8. Vet JN, de Boer MA, van den Akker BE, Siregar B, Lisnawati, et al. Prevalence of human papillomavirus in Indonesia: a population-based study in three regions. Bri J Cancer 2008; 99(1): 214-8.

9. de Boer MA, Vet JN, Aziz MF, Cornain S, Purwoto G, van den Akker BE, et al. Human papillomavirus type 18 and other risk factors for cervical cancer in Jakarta, Indonesia. Official J Int Gynecol Cancer Society 2006; 16(5): 1809-14.

10. Carcopino X, Bolger N, Henry M, Mancini J, Boubli L, Olive D, et al. Evaluation of type-specific HPV persistence and high-risk HPV viral load quantitation in HPV-positive women under 30 with normal cervical cytology. J Med Virol 2011; 83(4): 637-43.

11. Hopman EH, Rozendaal L, Voorhorst FJ, Walboomers JMM, Kenemans P, Helmerhorst TJM. High risk human papillomavirus in women with normal cervical cytology prior to the development of abnormal cytology and colposcopy. Bri J Obtet Gynaecol 2000; 107(5): 600-4.

12. Sanclemente G, Gill DK. Human papillomavirus molecular biology and pathogenesis. J Eur Academy Dermatol Venereol 2002; 16(3): 231-40.

13. Abu J, Batuwangala M, Herbert K, Symonds P. Retinoic acid and retinoid receptors: potential chemopreventive and therapeutic role in cervical cancer. The Lancet Oncology 2005; 6(9): 712-20 .

14. Zur Hausen H. Cervical carcinoma and human papillomavirus: on the road to preventing a major human cancer. J Nat Cancer Institute 2001 21; 93(4): 252-3. 